\title{
Site effects on root characteristics and soil protection capability of two cover crops grown in South Bulgaria
}

\author{
Margarita L. Himmelbauer ${ }^{1 *}$, Violeta Vateva ${ }^{2}$, Ljudmila Lozanova ${ }^{2}$, \\ Willibald Loiskandl ${ }^{1}$, Svetla Rousseva ${ }^{2}$ \\ ${ }^{1}$ Institute of Hydraulics and Rural Water Management, University of Natural Resources and Life Sciences, Muthgasse 18, 1190 Vienna, \\ Austria. \\ 2 "N. Poushkarov" Institute of Soil Science, Shousse Bankya 7, 1080 Sofia, Bulgaria. \\ ${ }^{*}$ Corresponding author. E-mail: ml.himmelbauer@boku.ac.at
}

\begin{abstract}
Water erosion has been recognized as a major soil degradation process worldwide. This is of special relevance in the semi-arid areas of South Bulgaria with long periods of drought along with severe rainfall events. The main objective of this study was to evaluate the applicability of Bromus innermis L. and Lotus corniculatus L. for soil protection purposes under different site conditions. The site parameters considered were slope, fertilization and a range of soil physical parameters. The plant parameters were canopy cover, biomass, and root morphological characteristics. The experiment includes plots without and with eleven rates of NPK fertilization on gentle $\left(6^{\circ}\right)$ and steep slopes $\left(12^{\circ}\right)$. It was observed that the effect of fertilization on shoot and root growth was stronger on the gentle than on the steep slopes. The biomass accumulation was more sensitive to $\mathrm{N}$ than the PK fertilizer applications. The increase of the root density with increasing fertilization rates was more pronounced for the mass than for length or surface area. A significant effect on root diameter was found only for the variants with the highest $\mathrm{N}$ application. Treatments with the highest root mass density on both slopes showed the greatest potential for reducing erosion.
\end{abstract}

Keywords: Rangeland; Cover crops; Fertilization; Root characteristics; Slope protection.

\section{STATE OF ART}

Soil erosion is recognized as a widespread problem throughout Europe with large spatial and temporal variations in soil erosion processes and rates owing to the large diversity of landscapes, climate, soils and land use (Boardman and Poesen, 2006; Cerdan et al., 2010; García-Orenes et al., 2010). It is a primarily a result of inappropriate land management, deforestation, overgrazing, forest fires and construction activities, affecting 1.3 million $\mathrm{km}^{2}$ in the EU-27 (EC, 2012; García-Orenes et al., 2010) with total rates of sheet and rill erosion estimated at $550 \mathrm{Mt} \mathrm{y}^{-1}$ (Cerdan et al., 2010).

The territory of Bulgaria is $2.5 \%$ of the EU 27 area and contributes $3.8 \%$ of the total soil erosion estimate for EU-27 (Rousseva, 2012). This is of special relevance for rangelands in the semi-arid areas of Bulgaria characterized with long periods of drought along with intensive rainfall events (Rousseva, 2006). For semi-arid regions highly susceptible to fluvial erosion, an analysis of vegetation characteristics and soil properties are essential to gain an insight into the relevant processes (Baets et al., 2009; Cerdà and Doerr, 2005, Martinez-Murillo et al., 2012).

Vegetation cover and root persistence in the topsoil are assumed to be key factors for controlling soil erosion, due to influences on soil formation, stability, anti-scourability (Cerdà, 1998; Gyssels and Poesen, 2003). The magnitude of influence is a factor of vegetation type and its impacts on soil hydrophobicity (e.g. Lichner et al., 2012), for example herbs were identified as most efficient for soil erosion control (Cerda and Doerr, 2005). When the canopy biomass is lost, root growth that is close to the soil surface can reduce surface runoff (Duran and Rodriguez, 2008). In addition, roots have profound effect on soil structure stability as they contribute to formation of soil aggregates by rhizodeposition, increase soil permeability by enhancing water infiltration rate and mechanically support soil shear strength. Nevertheless, the majority of erosion-related studies have overlooked root effects and focused on the impact of vegetation cover only. Over the last decade, this 'hidden' aspect has received increasingly attention and there are more detailed studies on the interactions between root morphological characteristics and soil erosion attenuation (Gyssels et al., 2006; Stokes et al., 2007; Reubens et al., 2007; Zhou and Shangguan, 2005, 2007; Burylo et al., 2012).

Plant species with different root systems have dissimilar erosion-reducing effects. For slope stabilization, deep rooting systems such as tap root systems are more suitable, while dense lateral-spreading roots as by fibrous root systems seem to be more effective for surface water erosion (Gyssels et al., 2005). Anchorage of roots in soil depends on a combination of parameters, i.e. number, depth, diameter, branching characteristics, which are further influenced by the soil conditions (Dupuy et al., 2005). A decline of soil losses by fluvial erosion with increasing root mass and root length densities was reported by Gyssels et al. (2005) and Knapen et al. (2007). Root length density is also a proper indicator for soil penetrability and water utilization by plants (e.g. Himmelbauer et al., 2010, 2012). According to Li et al. (1991), length density of fine roots and not their total length is suitable for expressing the root-soil contact area and thus is highly instrumental in controlling soil losses. Zhou and Shangguan (2005) agreed that root length density is an appropriate parameter but stated that the effect cannot be precisely predicted if only the number of fine roots is taken into account. The authors proposed root surface area density to be used when dealing with concentrated flow, since it included root diameter. De Baets et al. (2007a) also showed that root diameter is an important variable in explaining relative soil detachment rate. Samples containing dissimilar (tap and fibrous) root systems were examined to evaluate the root effect in reducing erosion rates by concentrated flow, and empirical relationships were derived for different soils (De Baets et al., 
2007ab; De Baets and Poesen, 2010). Root tensile strength is a factor to be considered when selecting plants for strengthening soil slope stability (Stokes et al., 2007). The tensile strength is size-dependent and regularly increases with decreasing the root diameter. Therefore, a systematic research approach on soil erosion reduction should consider a partitioning of roots in diameter classes.

The main objective of this study was to evaluate the applicability of two cover crops Bromus innermis L. and Lotus corniculatus L. for soil protection purposes under different site conditions. The site parameters considered were slope, fertilization, physical and chemical soil properties. The plant parameters were canopy cover, biomass and root morphology, i.e. mass, length, surface area, average diameter and diameter classes.

\section{MATERIAL AND METHODS}

\section{Climate and soil conditions}

The study site was an experimental field of the "N. Pushkarov" Institute of Soil Science, situated in Sakar Mountain, Southeast Bulgaria. The climate is continental to Mediterranean characterized by mild winters and hot summers. An increased number of days with extreme precipitation (about $60 \%$ ) and thunderstorm events have been observed for the last two decades, despite of the general decrease in the total rainfall amount (Simeonov et al., 2007). The long-term average annual air temperature is $12.2^{\circ} \mathrm{C}$. The annual average precipitation approximates $526 \mathrm{~mm}$ with rainfall sums from April until October (the growing period) of $284.2 \mathrm{~mm}$. The soil at the site is classified as Chromic Luvisol (LVx) (Boyadgiev, 1994). It belongs to the group of soils moderately resistant to acidification with a medium $\mathrm{pH}$ values, CEC of $35-60 \mathrm{meq} / 100 \mathrm{~g}$ and domination of 2 : 1 clay minerals such as Vermiculite (Kolchakov et al., 2005). The site is located on gentle $\left(6^{\circ}\right)$ to steep slopes $\left(12^{\circ}\right)$.

\section{Experimental setup and root sampling}

Two cover crops - a leguminous Bird's-foot trefoil (Lotus corniculatus L.) and a perennial grass, Bromegrass (Bromus innermis, L.) - were examined. Different species growing in a composed system naturally occupy different places and often use different soil exploration strategies (Perriet et al., 2007). Bromus innermis L. belongs to the grass family (Poaceae). It prefers deep fertile well-drained soils. The crop has a long vegetation period starting early in spring and continues late in fall. Its dense root system enables the plant to survive long-term dry periods. The roots spread also horizontally and produce abundant rhizomes, which makes the crop useful for erosion control, since shallow but dense root nets support mechanical reinforcement of soils. Lotus corniculatus L. is a perennial, herbaceous member of the pea family (Fabaceae). It prefers well-drained soil, but it is also drought-tolerant. The root system includes a long tap root, which may reach $1 \mathrm{~m}$ depth, a fibrous mat of secondary roots, and modified stems near the soil surface.

A long term experiment was primary set up to test effects of mineral fertilization on cover cropping and on soil erosion on two positions: a gentle slope of $6^{\circ}$ and on a steep slope of $12^{\circ}$ (Vateva and Lozanova, 2006). The cropping system was a mixture of Bird's-foot trefoil and Bromegrass in proportion 40 to $60 \%$. The experiment consisted of $20 \mathrm{~m}^{2}$ plots with application of 11 different rates of NPK fertilization (N60P60, N60K60, P60K60, N60P60K60, N120P120K60, N180P180K60, N60P120K60, N120P60K60, N180P120K60, $\mathrm{N} 60 \mathrm{P} 60 \mathrm{~K} 60+\mathrm{Mo}, \mathrm{N} 60 \mathrm{P} 60 \mathrm{~K} 60+\mathrm{CaO})$ and control plots without fertilization (NOP0K0) in 4 replications. The crops were sown in the spring. In the autumn preceding the sowing, the soil was ploughed to a depth of $25 \mathrm{~cm}$ followed by cultivation and disking immediately before sowing. Thereafter, there is no cultivation applied. The fertilizer application, expressed in $\mathrm{kg} \mathrm{ha}^{-1}$, was stopped 3 years before the study reported in this paper. Thus, only the sequential effects of the remaining soil fertility on the root growth were examined. A series of soil and plant growth characteristics were continuously measured during the experiment. The monitoring of the crop population- vegetation cover and the botanical composition- was conducted by counting the number of the species per square meter.

For the root observation, the method of the soil monolith was used since it is suitable for narrow plant spacing. Soil monoliths of $20 \times 20 \mathrm{~cm}$ were excavated up to $30 \mathrm{~cm}$ soil depth (topsoil) in each of the plots at the end of the vegetation period in August - September. Roots were washed out from the monoliths by hand over a set of sieves in situ. Field collected root samples are generally large and handling them individually can tremendously increase the treatment time. For this reason, representative root sub-samples per treatment on the gentle and the steep slopes, pooled samples of the thoroughly mixed replicates, were taken and stored until further analyses. The rest parts of the samples were immediately oven dried $\left(60^{\circ} \mathrm{C}\right)$ for dry mass. In the laboratory, the root sub-samples were first treated for measuring their geometrical parameters (length, surface area, average diameter and diameter classes) using image analysis following Himmelbauer et al. (2004). After the image analysis, the root sub-samples were also oven dried and particular ratios of their dry mass to the length and to the surface area values were calculated for each treatment. These proportions were further used to estimate the total length and surface area per variant. Root density expressed as mass, length and surface area of roots per volume or area of soil were calculated.

In order to explore the erosion-reducing potential of the cover crop roots, empirically based equations were applied. The first one is derived for fine root systems only:

$\mathrm{RSD}=\mathrm{e}^{-2,58 \mathrm{RD}}$,

where RSD is relative soil detachment rate (indicator for soil erodibility) and $\mathrm{RD}$ is root mass density of fine roots having diameter $\leq 1 \mathrm{~mm}\left(\mathrm{~kg} \mathrm{~m}^{-3}\right)$, (Eq. (3) in Baets et al., 2007a).

The second one was derived for a mixture of fibrous and tap root systems grown on silt loam topsoil:

$\mathrm{RSD}=\mathrm{e}^{-2.24 \mathrm{RD}} * \mathrm{e}^{146.67 \mathrm{RD} * \mathrm{D}}$,

where the RD is root mass density $\left(\mathrm{kg} \mathrm{m}^{-3}\right)$ and $\mathrm{D}$ is the mean root diameter of the root sample (mm), (Eq. (10), De Baets et al., 2007b).

The third equation was proposed for mixed plant communities and roots on loamy topsoil:

$\mathrm{RSD}=\mathrm{e}^{(-1.25 \mathrm{RD}+0.06 \mathrm{RD} \times \mathrm{D})}$,

where the RD is root mass density $\left(\mathrm{kg} \mathrm{m}^{-3}\right)$ and $\mathrm{D}$ is the mean root diameter of the root sample (mm), (Eq. (11)), De Baets and Poesen, 2010).

For Eq. (1), the obtained root densities of the fine roots thinner than $1 \mathrm{~mm}$ were used, while for the Eq. (2) and Eq. (3), the root mass densities of all root classes were considered.

The soil-erosion parameter RSD is a ratio between the absolute soil detachment rates for root-grown soil samples against 
the bare soil samples. Soil detachment rate $\left(\mathrm{kg} \mathrm{s}^{-1} \mathrm{~m}^{-2}\right)$ gives gravimetric sediment concentration changes with average runoff discharge over the soil surface area. The RSD specifies the erosion-reducing potential as follows: 0.01 states for very high resistance against erosion, values greater than 0.50 are for very low resistance, and the values in-between represent different levels of erosion-reducing potential.

\section{RESULTS AND DISCUSSIONS Soil properties}

Measured soil parameters as averaged per slope position are presented in Table 1. The soil is classified as sandy clay loam. The soil parameters suggest rather unfavourable growth conditions especially on the steep slope position having acidified topsoil with $\mathrm{pH}$ below 5.0, high bulk density of 1.6 to 1.7 $\mathrm{g} \mathrm{cm}^{-3}$, moderate hydraulic conductivity of 2 to $3 \mathrm{~cm} \mathrm{~d}^{-1}$ and very low humus content of 0.4 to $0.8 \%$ (Table 1 ). As often reported, the soil is more vulnerable to erosion processes where organic matter content is low (e.g. García-Orenes et al., 2009).

Large air-filled pores provide paths for vigorous root growth. The accepted critical thresholds for air-filled porosity are between $10 \%$ (volumetric) for clay and $15 \%$ for sandy soils, lower values restrict root respiration and uptake (Hakansson and Lipiec, 2000). In this study, the measured airfilled porosity for the sites was generally higher than the cited limits, except for the steep slope where the air-porosity dropped to $3.6 \%$ at a soil depth greater than $20 \mathrm{~cm}$, indicating more difficult root growth conditions.

\section{Vegetation and root growth}

Results on vegetation characteristics of Bromus innermis L. (called further Bromus inn.) and Lotus corniculatus L. (called Lotus c.) are presented in Fig. 1. With increasing fertilization rates, the canopy cover increased by $20 \%$ compared to the control (variant 1). Maximum values of 67 on the steep and 72 $\%$ on the gentle slope were achieved in variant 7 (N180P180K60) with the highest rate of fertilizer application. Studying the composition of the cover, it was observed that Bromus inn. dominated the initial sowing rate of $60 \%$ and dominated in most trials, except for variant 4 (N0P60K60) a phosphorus $(\mathrm{P})$ - potassium fertilizer $(\mathrm{K})$ was applied, but not nitrogen $(\mathrm{N})$. On these plots, the proportion of the Lotus $c$. reached $40 \%$ on the gentle and $50 \%$ on the steep slope. The canopy cover of Bromus inn. increased with increased application rates of $\mathrm{N}$. This effect was more pronounced on the gentle slope.

The above-ground biomass is an important soil surface protection, as it reduces raindrop collision, prevents crust formation, and controls the amount of infiltrated and intercepted rainwater. In this study, the plant biomass considerable increased with increasing fertilizer rates, especially in variants 7 (N180P180K60) and 10 (N180P120K60) where the highest rates were applied (Fig. 2). In general, the total plant biomass accumulation was more sensitive to $\mathrm{N}$ than the $\mathrm{P}$ and $\mathrm{K}$ fertilizer applications. In addition, the effect was more pronounced on the gentle than on the steep slopes, and on the above ground than on the below ground biomass. The estimated shoot to root (mass) ratios for the different treatments did not differ considerably. The shoot: (top-) root ratios were slightly higher for the steep slopes and for variants with low fertilization rates, i.e. var. 2 (N60P60) and var. 3 (N60P60K60), or no fertiliser (var. 1), suggesting there was deeper (subsoil) root growth. The root results represent all types of roots in the topsoil, i.e. the fibrous

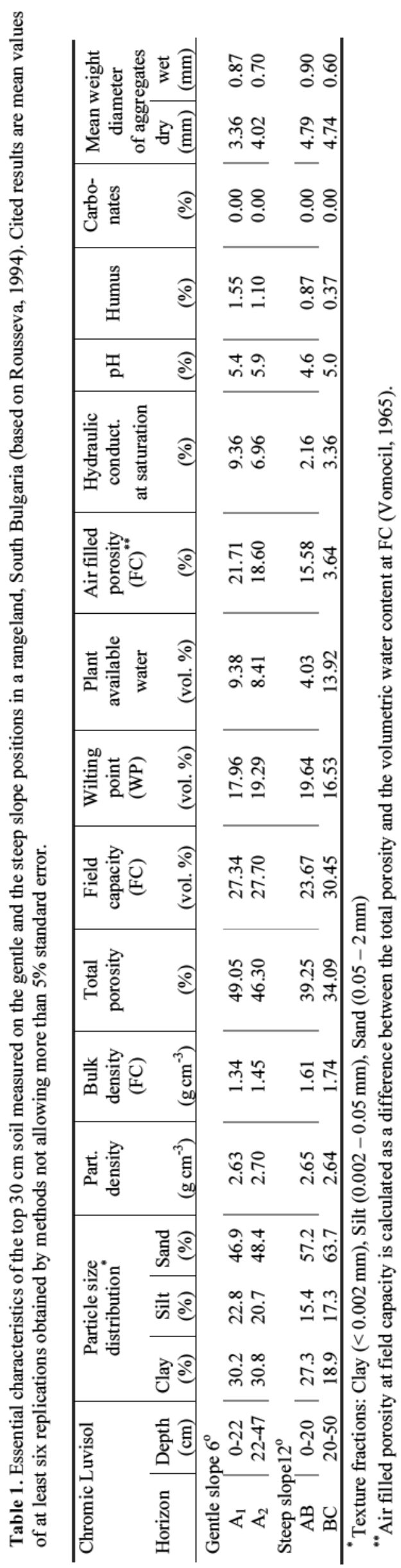


a)

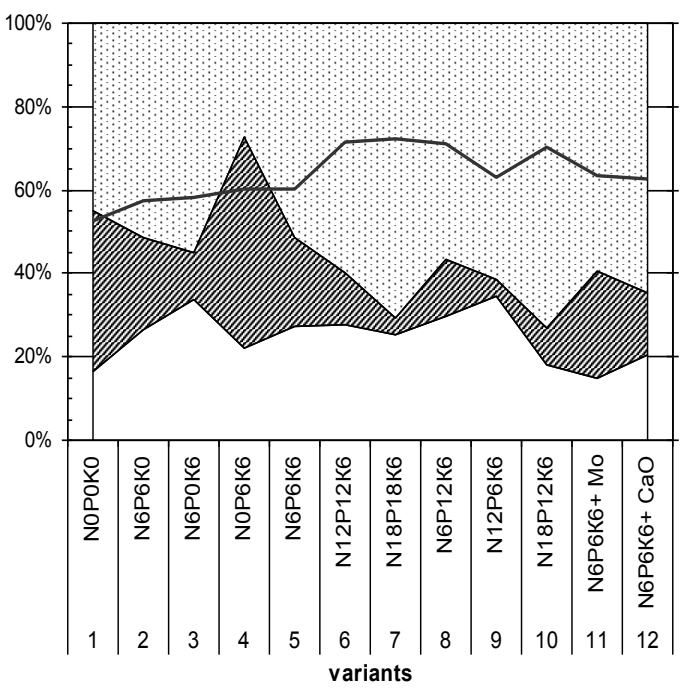

b)

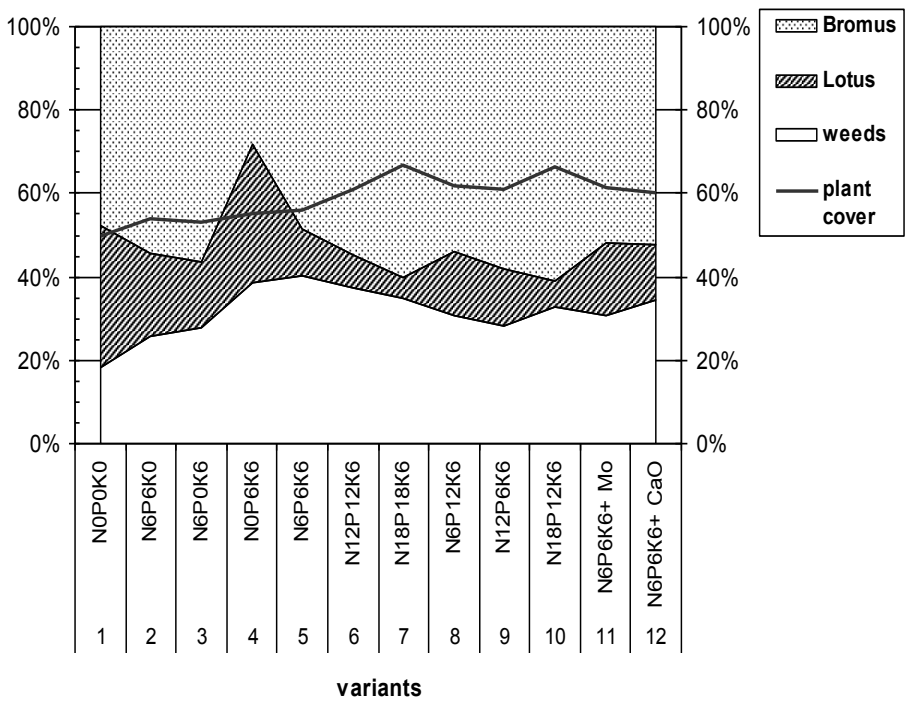

Fig. 1. Vegetation cover and botanical composition for the different rates of fertilizer application on a) gentle $\left(6^{\circ}\right)$ and b) step $\left(12^{\circ}\right)$ slopes.

a)

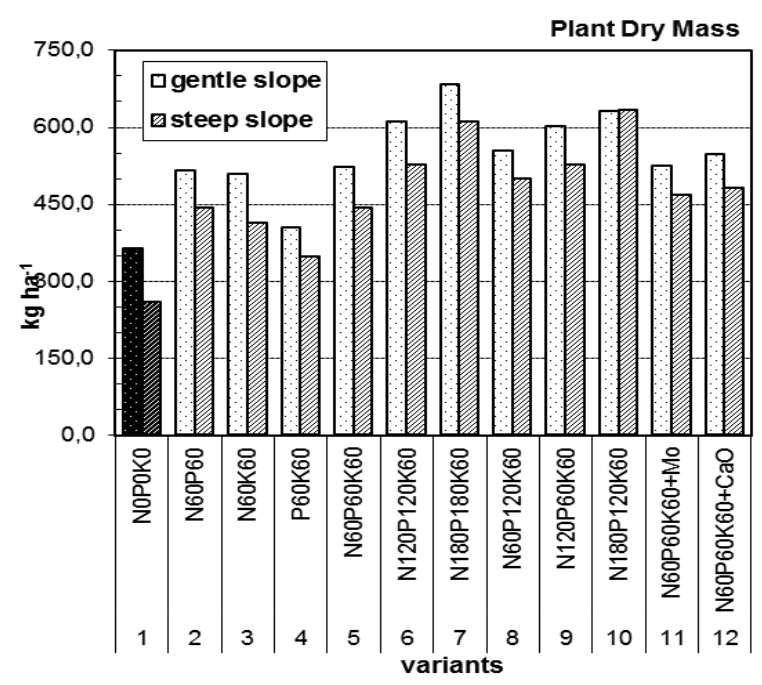

b)

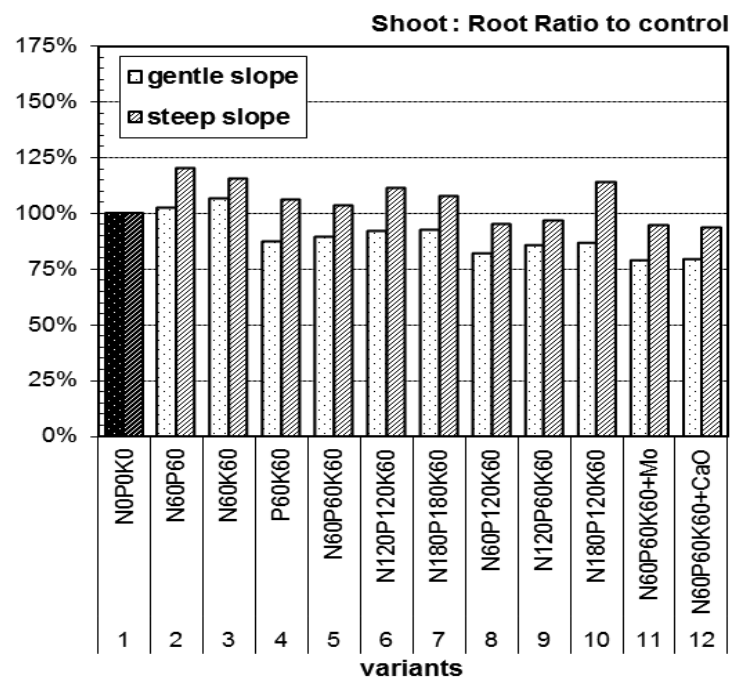

Fig. 2. Results for a) the aboveground dry mass and b) calculated Shoot to Root Ratios relative to the control (variant 1 ) on the gentle and the steep slopes.

root of Bromus inn. and the tap roots of Lotus c., since it was neither possible nor practicable to distinguish between both root systems in situ. Thus, an intermediate differentiation was done considering one typical root morphology and the observed partitioning of the vegetation composition.

Nutrient contents $(\mathrm{N}, \mathrm{P}, \mathrm{K}$ and $\mathrm{Ca}$ ) accumulated in the root biomass relative to the control are presented on Figs 3. As expected, stronger responses were mainly observed in the plots with the highest fertilization rates. Root accumulation of N, K and $\mathrm{Ca}$ was significantly higher (up to $400 \%$ ) in all fertilized variants compared to the control (var. 1). Rather minor effects were found with respect to the $\mathrm{P}$ application. The $\mathrm{P}$ contents were comparable in all variants with a maximum measured in var. 7 with the highest $P$ rate. In general, greater responses were observed for the roots on the steep slopes, in particular for $\mathrm{K}$ (Fig. 3). The measured absolute nutrient concentrations were lower on the steep slope positions than on the gentle slopes, probably due to nutrient leaching down the soil profile.
Measured root morphological parameters are shown on Fig. 4. Except for root mass, the root length and surface area densities (roots per volume of soil) did not consistently increase with increasing rates of fertilizer application. At the same time the root densities were highly sensitive to the shortage of $\mathrm{N}$ in the soil. Results for var. 4 (P60K60, no N application) on the steep slope were even lower than those for the control (var. 1). The results of the botanical composition (Fig. 1) show that in var. 4, Lotus c. having a tap root system dominated. The highest length and surface area densities were observed in variants 6 $(\mathrm{N} 120 \mathrm{P} 120 \mathrm{~K} 60)$ and $12(\mathrm{~N} 60 \mathrm{P} 60 \mathrm{~K} 60+\mathrm{CaO})$ with moderate to high rates of fertilization. In these plots, the proportion of Lotus c. plants was lower compared to Bromus inn. The variant 12 clearly showed a positive root response to the added calcium (Ca) in the fertilizer. Under calcium deficient conditions, the building of the cell walls structure is generally suppressed; roots remain short, brownish and have difficulties transmitting water. In our case, the Ca application apparently supported the root extension expressed as length and surface area density. 
This effect was more pronounced on the gentle than on the steep slopes. Concerning the average root diameter, the results for the steep slope were slightly higher than for the gentle slope, except for the control. The average diameters were mainly between 0.3 and $0.4 \mathrm{~mm}$, but enlarged with increasing the $\mathrm{N}$ fertilisation rate. The largest average diameter of $0.48 \mathrm{~mm}$ was measured for the steep slope in variant 10 with the highest $\mathrm{N}$ application.

Gyssels et al. (2005) found that roots having a diameter less than $3 \mathrm{~mm}$ were more important to soil fixation than coarser roots, especially for surface slope stability where shallow but dense root networks are most effective. Li et al. (1991) stated that soil erosion resistance mainly depends on the number of roots thinner than $1 \mathrm{~mm}$. In addition, fine roots have faster turnover rates and degrade more rapid in soil organic matter which supports soil aggregation.

The measured proportions of the root length according to the three main diameter classes: $\leq 0.5 \mathrm{~mm}$ (very fine roots),$\leq 1$ $\mathrm{mm}$ (fine roots) and larger than $1 \mathrm{~mm}$ (coarse roots), are shown in Fig. 5. The var. 10 (the highest $\mathrm{N}$ rate) had the highest percentage of the coarse roots of $4.5 \%$. The root surface area distribution according to the same diameter classes is shown in Fig. 6. For var. 10, the proportions of coarse roots surface area were $11 \%$ on the gentle and $12 \%$ on the steep slopes. Similar results were obtained for var. $6(\mathrm{~N} 120 \mathrm{P} 120 \mathrm{~K} 60)$ with high NP rate. This diameter class of roots thicker than $1 \mathrm{~mm}$ corresponds to the size of the tap (seminal) roots or the rhizomes, but not the root branches. Regarding the very fine roots thinner than $0.5 \mathrm{~mm}$, no strong effect was observed in relation to fertilizer rates. Some losses of fine root material may also occur during the root washing in situ and the storage until later analyses.

Comparisons between the results for the gentle and steep slopes using analysis of variance $(\mathrm{P}<0.05$, here not shown) showed that root mass density, surface area density and average diameter of roots did not differ significantly. At the same time, the root length density and the plant biomass production were considerably higher on the gentle slope than on the steep slope.

\section{Erosion reducing potential}

Plant species with dissimilar root systems display different erosion-reducing effects. Grasses and lateral-rooted plants are generally assumed to be more effective in reducing concentrated flow erosion than tap-rooted plants. Relationships between morphological characteristics of topsoil roots and their erosionreducing potential were derived for different soils (De Baets et al., 2007ab; De Baets and Poesen, 2010). The proposed equations are suitable for examining different crops for their capability to reduce soil loses by erosion.
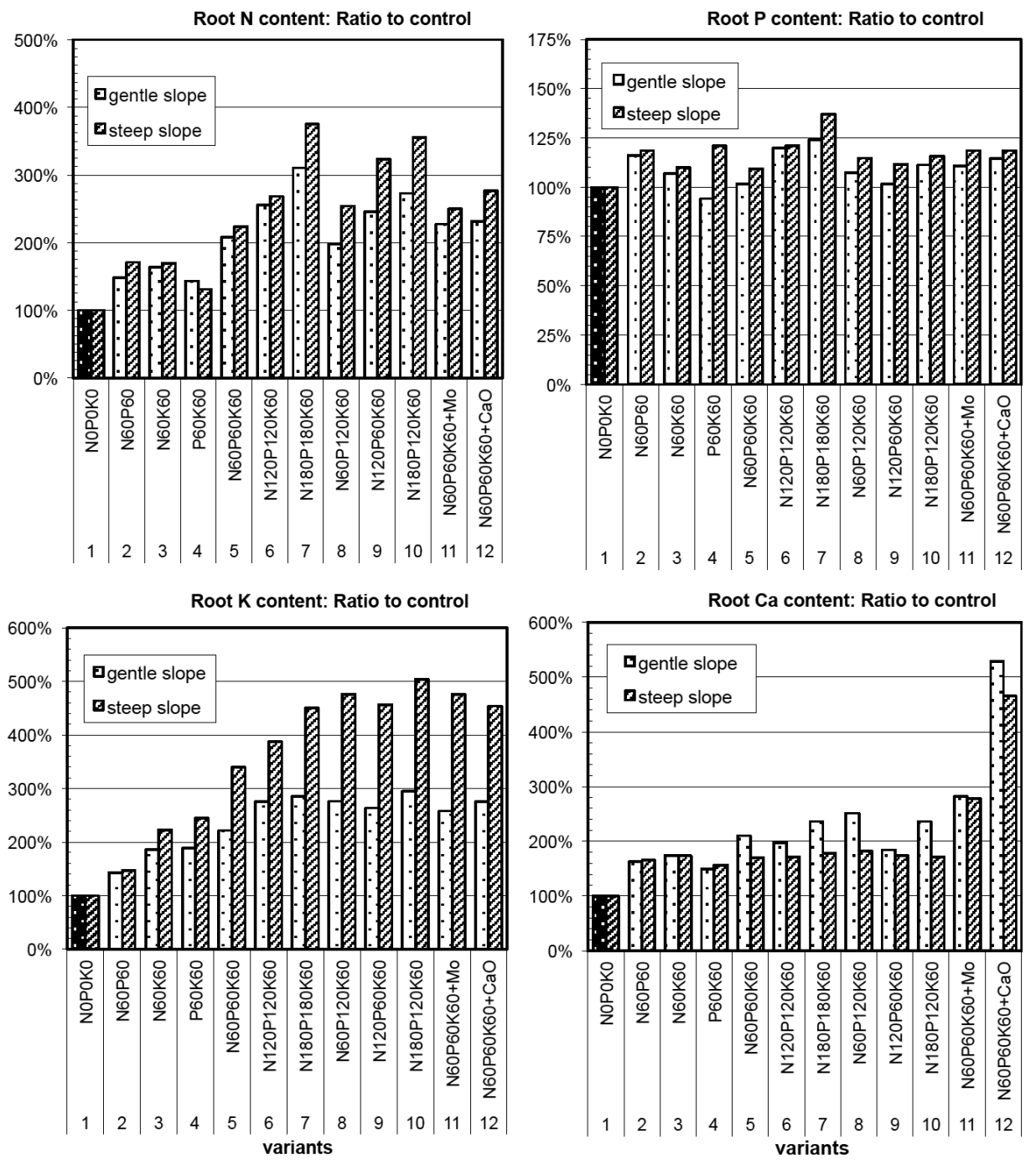

Fig. 3. Accumulation of nitrogen $(\mathrm{N})$, phosphorus $(\mathrm{P})$, potassium $(\mathrm{K})$ and calcium $(\mathrm{Ca})$ in the roots measured in the top $30 \mathrm{~cm}$ soil depth for all variants of fertilization as proportions to the control (variant 1 ) on the gentle and the steep slopes. 
In this study, mixtures of fibrous and tap root systems were tested. The root diameter results showed that the pooled root samples principally consist of fine roots thinner than $1 \mathrm{~mm}$. Three equation for estimation the erosion-reducing potential (soil-detachment rate) of the topsoil roots were applied here: equations 1 for fine roots on sandy loam (De Baets et al., 2007a), Eq. (2) for mixed (fine and coarse) roots on silt loam (De Baets et al., 2007b), and Eq. (3) for mixed (bur generally fine) roots on loam topsoil (De Baets and Poesen, 2010). The estimated results are presented in Table 2.

The estimated relative soil detachment rates vary for the three equations used, but the results are below 0.01 suggesting a very high erosion-reducing potential of the topsoil roots in all treatments. The highest values (i.e. lower resistance against erosion) are estimated for var. 1 (without fertilization), while the lowest values (i.e. maximum erosion-reducing potential) are found for var. 7 (the highest rate of fertilization) having the highest root mass density on both slopes. It is important to point out that the presented estimations are only indirect indications for the soil erosion potential of the examined root mixtures.

Along with the cropping and rooting systems, the land management is an essential factor for soil degradation and erosion diminishing, for the reason that cultivation affects soil physical, chemical and biological properties. It is well known that, soil cultivation influenced root growth, distribution and morphological characteristics (e.g. Himmelbauer et al., 2010, 2012). In this study, no tillage was applied for the last few years of the experiments on both slopes. This allowed a development of sturdy canopy cover mixtures including weeds, which support slope stability. Similar strategies for erosion control using weeds lonely or in combination with straw mulch have been newly reported as very efficient in reducing soil losses in semiarid agro-ecosystems (García-Orenes et al., 2009, 2010).
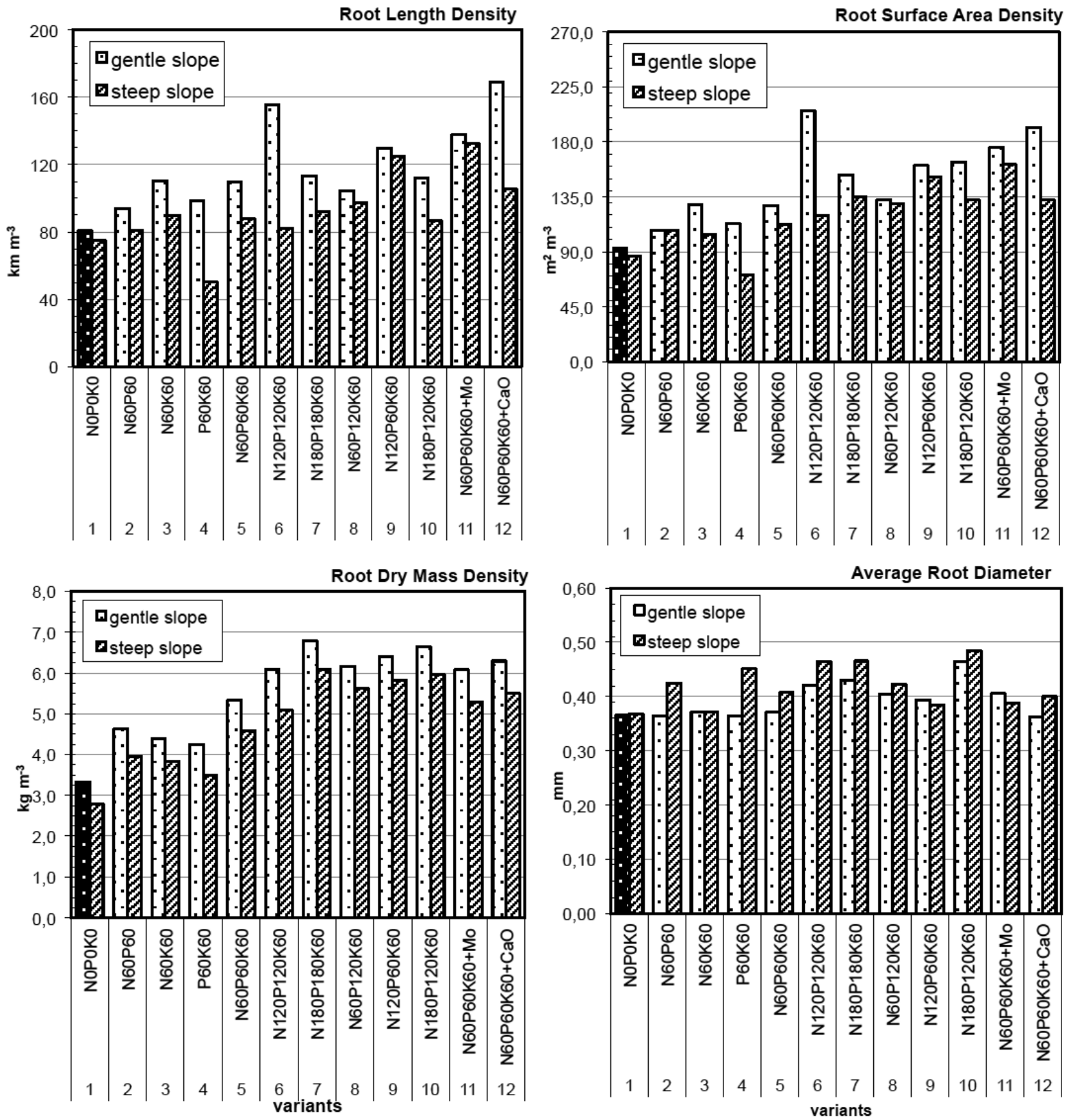

Fig. 4. Root morphological parameters: root length density $\left(\mathrm{km} \mathrm{m}^{-3}\right)$, root surface area density $\left(\mathrm{m}^{2} \mathrm{~m}^{-3}\right)$, root dry mass density $\left(\mathrm{kg} \mathrm{m}^{-3}\right)$ and average root diameter $(\mathrm{mm})$ measured in the topsoil of $30 \mathrm{~cm}$ for all variants of fertilization on the gentle and steep slopes. 


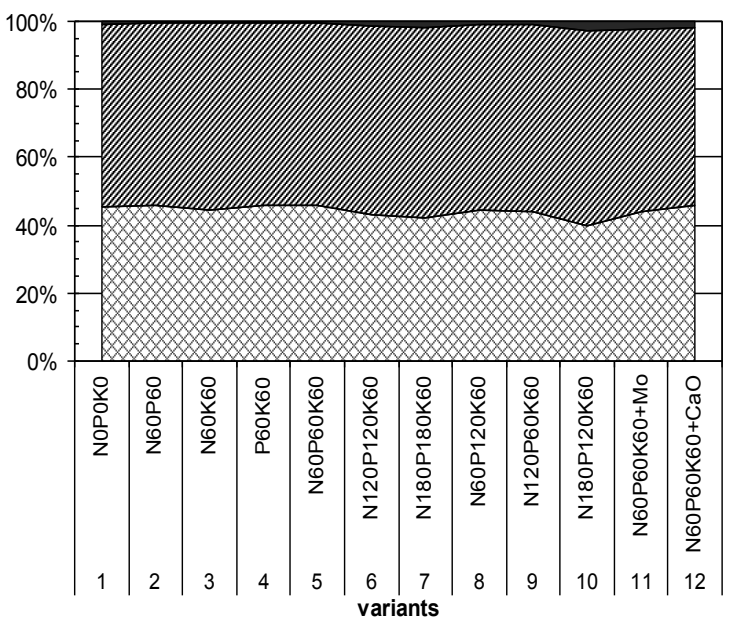

b)

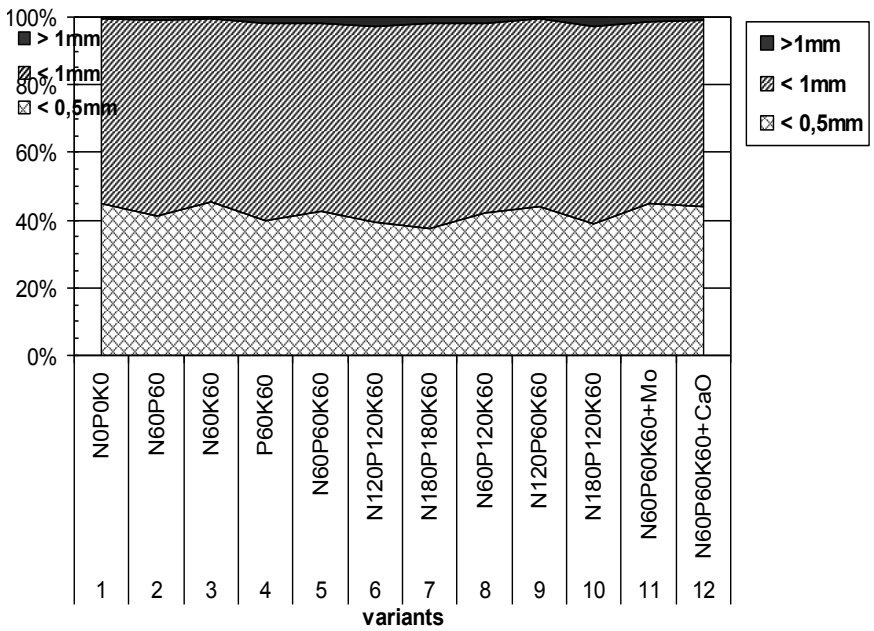

Fig. 5. Percentage distributions of the root length according to the diameter classes below $0.5 \mathrm{~mm}$ (very fine roots), below $1 \mathrm{~mm}$ (fine roots) and larger than $1 \mathrm{~mm}$ (coarse roots) on a) gentle and b) steep slopes.

a)

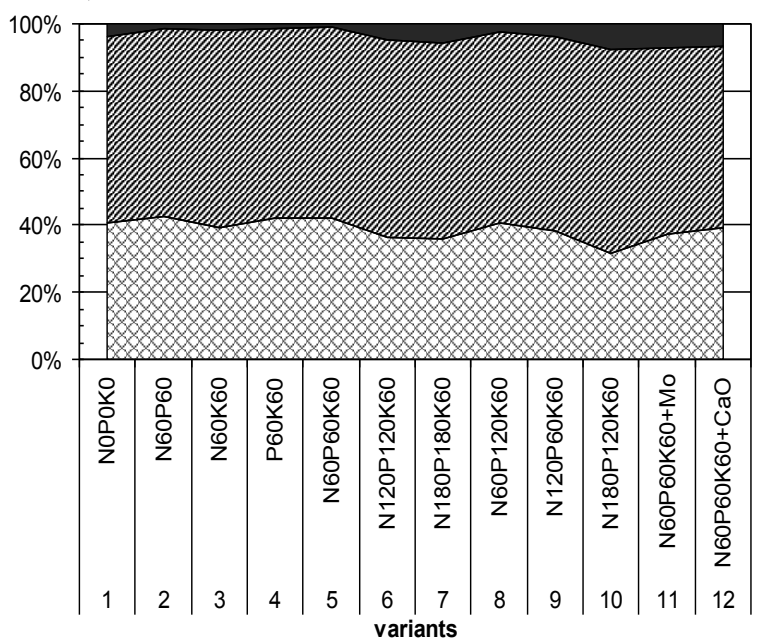

b)

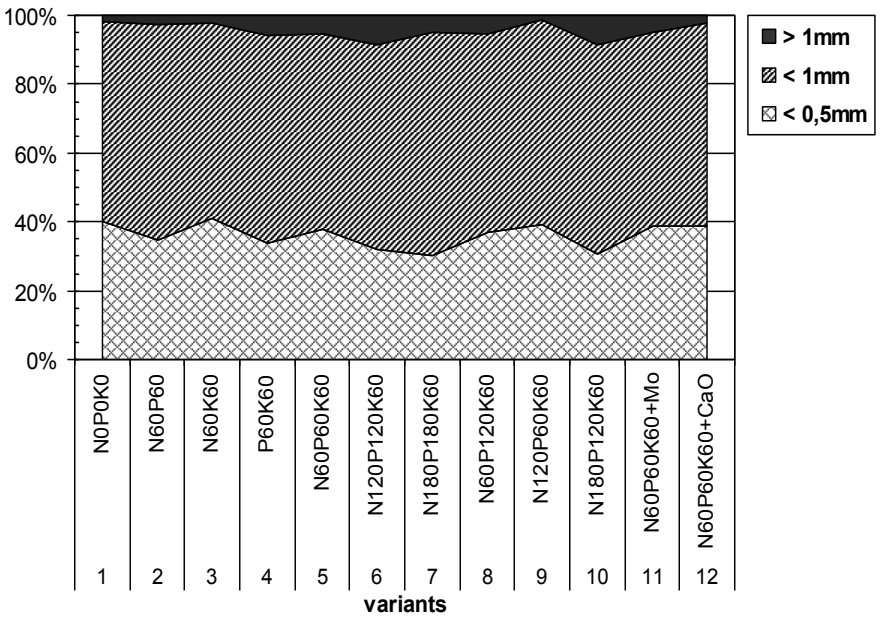

Fig. 6. Percentage distributions of the root surface area according to the diameter classes below $0.5 \mathrm{~mm}$ (very fine roots), below $1 \mathrm{~mm}$ (fine roots) and larger than $1 \mathrm{~mm}$ (coarse roots) on a) gentle and b) steep slopes.

Table 2. Erosion-reducing potential of the topsoil including roots of Bromus innermis L. and Lotus corniculatus L. calculated for the different fertilization treatments on the gentle and steep slopes.

\begin{tabular}{|c|c|c|c|c|c|c|}
\hline $\begin{array}{l}\text { Variants } \\
\text { Position }\end{array}$ & $\operatorname{RSD}^{\#}$ (Eq. (1)) & $\begin{array}{c}\text { RSD (Eq. (2)) } \\
\text { Gentle slope }\end{array}$ & RSD (Eq. (3)) & RSD (Eq. (1)) & $\begin{array}{l}\text { RSD (Eq. (2)) } \\
\text { Steep slope }\end{array}$ & RSD (Eq. (3)) \\
\hline 1. $\mathrm{N}_{0} \mathrm{P}_{0} \mathrm{~K}_{0}$ & 2.14E-04 & 6.83 E-04 & $1.67 E-02$ & 8.13E-04 & 2.27E-03 & $3.28 E-02$ \\
\hline 2. $\mathrm{N}_{60} \mathrm{P}_{60}$ & $7.17 \mathrm{E}-06$ & $4.05 \mathrm{E}-05$ & $3.41 \mathrm{E}-03$ & $4.37 \mathrm{E}-05$ & $1.80 \mathrm{E}-04$ & $7.85 \mathrm{E}-03$ \\
\hline 3. $\mathrm{N}_{60} \mathrm{~K}_{60}$ & $1.41 \mathrm{E}-05$ & 7.03E-05 & 4.65E-03 & $5.68 \mathrm{E}-05$ & $2.29 \mathrm{E}-04$ & $9.04 \mathrm{E}-03$ \\
\hline 4. $\mathrm{P}_{60} \mathrm{~K}_{60}$ & $1.90 \mathrm{E}-05$ & $9.20 \mathrm{E}-05$ & $5.41 \mathrm{E}-03$ & $1.64 \mathrm{E}-04$ & $4.96 \mathrm{E}-04$ & $1.38 \mathrm{E}-02$ \\
\hline 5. $\mathrm{N}_{60} \mathrm{P}_{60} \mathrm{~K}_{60}$ & $1.15 \mathrm{E}-06$ & $8.65 \mathrm{E}-06$ & $1.43 \mathrm{E}-03$ & $1.04 \mathrm{E}-05$ & $4.57 \mathrm{E}-05$ & $3.64 \mathrm{E}-03$ \\
\hline 6. $\mathrm{N}_{120} \mathrm{P}_{120} \mathrm{~K}_{60}$ & $2.32 \mathrm{E}-07$ & $1.75 \mathrm{E}-06$ & $5.81 \mathrm{E}-04$ & $3.86 \mathrm{E}-06$ & $1.60 \mathrm{E}-05$ & $2.00 \mathrm{E}-03$ \\
\hline 7. $\mathbf{N}_{180} \mathbf{P}_{180} K_{60}$ & 4.36E-08 & 3.79E-07 & 2.45E-04 & 2.34E-07 & $1.82 E-06$ & 5.91E-04 \\
\hline 8. $\mathrm{N}_{60} \mathrm{P}_{120} \mathrm{~K}_{60}$ & $1.51 \mathrm{E}-07$ & $1.44 \mathrm{E}-06$ & $5.21 \mathrm{E}-04$ & $7.81 \mathrm{E}-07$ & 4.77E-06 & $1.02 \mathrm{E}-03$ \\
\hline 9. $\mathrm{N}_{120} \mathrm{P}_{60} \mathrm{~K}_{60}$ & $9.09 \mathrm{E}-08$ & $8.44 \mathrm{E}-07$ & $3.86 \mathrm{E}-04$ & $3.28 \mathrm{E}-07$ & $2.94 \mathrm{E}-06$ & $7.80 \mathrm{E}-04$ \\
\hline 10. $\mathrm{N}_{180} \mathrm{P}_{120} \mathrm{~K}_{60}$ & $7.75 \mathrm{E}-08$ & $5.43 \mathrm{E}-07$ & $2.98 \mathrm{E}-04$ & $4.13 \mathrm{E}-07$ & $2.39 \mathrm{E}-06$ & $6.86 \mathrm{E}-04$ \\
\hline 11. $\mathrm{N}_{60} \mathrm{P}_{60} \mathrm{~K}_{60}+\mathrm{Mo}$ & $2.82 \mathrm{E}-07$ & $1.73 \mathrm{E}-06$ & $5.78 \mathrm{E}-04$ & $1.64 \mathrm{E}-06$ & $9.61 \mathrm{E}-06$ & $1.52 \mathrm{E}-03$ \\
\hline 12. $\mathrm{N}_{60} \mathrm{P}_{60} \mathrm{~K}_{60}+\mathrm{CaO}$ & $1.52 \mathrm{E}-07$ & $1.05 \mathrm{E}-06$ & $4.40 \mathrm{E}-04$ & $8.43 \mathrm{E}-07$ & $6.16 \mathrm{E}-06$ & $1.18 \mathrm{E}-03$ \\
\hline
\end{tabular}

RSD is relative soil detachment rate: $0<\mathrm{RSD}<0.01$ is very high erosion-reducing potential, $0.01<\mathrm{RSD}<0.10$ is high erosion-reducing potential, $0.10<\mathrm{RSD}<0.25$ is medium erosion-reducing potential, $0.25<\mathrm{RSD}<0.50$ is low erosion-reducing potential, RSD $>0.50$ is very low erosion-reducing potential (De Baets et al., 2007a). 


\section{CONCLUSIONS}

Plant above-ground biomass of the two cover crops Bromus innermis L. and Lotus corniculatus L. was observed to be more sensitive to the fertilizer application than the below-ground (root) mass. The biomass accumulation was more sensitive to $\mathrm{N}$ than the PK fertilizer applications. These effects were stronger on the gentle than on the steep slope positions. The shoot: root ratios were higher for the variants without or with a low fertilization rate and for the steep slope positions. The increase of the root density with increasing fertilization rates was more pronounced for the mass than for length or surface area. At the same time, the root growth was sensible to the shortage of sufficient $\mathrm{N}$ content in the soil. A significant effect on root diameter was found only for the variants with the highest $\mathrm{N}$ application. Treatments with the highest root mass density on both slopes showed the highest potential for reducing erosion.

The presented results are principally valid for the cover crops, locations, soil and climate conditions examined, but they are applicable for ranking of species and rooting systems for slope protection purposes. At the same time, the findings are essential for the local rangeland management, since comparative studies are still missing in Bulgaria

Acknowledgement. We thank the ÖFG for the six month fellowship of Dr. M. Himmelbauer at the "N. Poushkarov" Institute of Soil Science, Sofia, Bulgaria. The work on the manuscript was partly supported by a grant from the Slovak Academic Information Agency, Action Austria- Slovakia (ICM-2012-00327). We are grateful also to Tim Cassidy for revision of the English text and to the referees for constructive comments on the manuscript.

\section{REFERENCES}

Boardman, J., Poesen, J., 2006. Soil Erosion in Europe. John Wiley \& Sons Ltd., London, pp. 855.

Boyadgiev, T., 1994. Soil map of Bulgaria according to the FAO-UNESCO-ISRIC revised legend explanatory notes. SoilScience, Agrochemistry and Ecology, N 4-6, p. 52-56.

Burylo, M., Rey, F., Mathys, N., Dutoit, T., 2012. Plant roottraits affecting the resistance of soils to concentrated flow erosion. Earth Surface Processes and Landforms, Vol. 37, $14,1463-1470$.

Cerdà, A., 1998. The influence of aspect and vegetation on seasonal changes in erosion under rainfall simulation on a clay soil in Spain. Canadian Journal of Soil Science, 78, 321-330.

Cerda, A., Doerr, S.H., 2005. Influence of vegetation recovery on soil hydrology and erodibility following fire: an elevenyear investigation. International Journal of Wildland Fire, $14,4,423-437$.

Cerdan, O., Govers, G., Le Bissonnais, Y., Van Oost, K, Poesen, J., Saby, N., Gobin, A., Vacca, A., Quinton, J., Auerswald, K., Klik, A., Kwaad, F.J.P.M., Raclot, D., Ionita, I., Rejman, J., Rousseva, S., Muxart, T., Roxo, M.J., Dostal, T., 2010. Rates and spatial variations of soil erosion in Europe: a study based on erosion plot data. Geomorphology, vol. 122, No 1-2, 167-177.

De Baets, S., Poesen, J., Knapen, A., Barberá, G., Navarro, J., 2007a. Root characteristics of representative Mediterranean plant species and their erosion-reducing potential during concentrated runoff. Plant and Soil, 294, 1-2, 169-183.
De Baets, S., Poesen, J., Knapen, A., Galindo Morales, P., 2007b. Impact of root architecture, soil characteristics and flow shear stress on the erosion-reducing potential of roots during concentrated flow. Earth Surface Processes and Landforms, 32, 1323-1345.

De Baets, S., Poesen, J., Reubens, B., Muys, B., De Baerdemaeker, J., Meersmans, J., 2009. Methodological framework to select plant species for controlling rill and gully erosion: application to a Mediterranean ecosystem. Earth Surface Processes and Landforms, 34, 1374-1392.

De Baets, S., Poesen, J., 2010. Empirical models for predicting the erosion-reducing effects of plant roots during concentrated flow erosion. Geomorphology, 118, 425-432.

Dupuy, L., Fourcaud, T., Stokes, A., 2005. A numerical investigation into the influence of soil type and root architecture on tree anchorage. Plant and Soil, 278, 119-134.

Durán, Z.V.H., Rodríguez, P.C.R., 2008. Soil-erosion and runoff prevention by plant covers. A review. Agron. Sustain. Dev., 28, 65-86.

EC, 2012. The Implementation of the Soil Thematic Strategy and Ongoing Activities. Report from the Commission to the European Parliament, the Council, the European Economic and Social Committee and the Committee of the Regions. COM (2012) $46 \mathrm{EN}$.

García-Orenes, F., Cerdà, A., Mataix-Solera, J., Guerrero, C., Bodí, M.B., Arcenegui, V., Zornoza, R., Sempere, J.G., 2009. Effects of agricultural management on surface soil properties and soil-water losses in eastern Spain. Soil and Tillage Research, 106, 117-123.

García-Orenes, F., Guerrero, C., Roldán, A., Mataix-Solera, J., Cerdà, A., Campoy, M., Zornoza, R., Bárcenas, G., Caravaca, F., 2010. Soil microbial biomass and activity under different agricultural management systems in a semiarid Mediterranean agroecosystem. Soil and Tillage Research, 109, 2, 110-115.

Gyssels, G., Poesen, J., Bochet, E., Li, Y., 2005. Impact of plant roots on the resistance of soils to erosion by water: a review. Progress in Physical Geography, 29, 189-217.

Gyssels, G., Poesen, J., 2003. The importance of plant root characteristics in controlling concentrated flow erosion rates. Earth Surface Processes and Landforms, 28, 371-384.

Gyssels, G., Poesen, J., Liu, G., Van Dessel, W., Knapen, A., De Baets, S., 2006. Effects of cereal roots on detachment rates of single- and double drilled topsoils during concentrated flow. European Journal of Soil Science, 57, 381-391.

Hakansson, I., Lipiec, J., 2000. A review of the usefulness of relative bulk density values in studies of soil structure and compaction. Soil and Tillage Research, 53, 71-85.

Himmelbauer, M.L., Loiskandl, W., Kastanek, F., 2004. Estimating length, average diameter and surface area of roots using two different image analysis systems. Plant and Soil, 260, 111-120.

Himmelbauer, M.L., Loiskandl, W., Rousseva, S., 2010. Spatial root distribution and water uptake of maize grown on field with subsoil compaction. Journal of Hydrology and Hydromechanics, 58, 3, 163-174.

Himmelbauer, M.L., Sobotik, M., Loiskandl, W., 2012. Notillage farming, soil fertility and maize root growth. Archives of Agronomy and Soil Science, Vol. 58, No. S1, 151-157, ISSN 0365-0340 print/ISSN 1476-3567 online.

Knapen, A., Poesen, J., De Baets, S., 2007. Seasonal variations in soil erosion resistance during concentrated flow for a loess-derived soil under two contrasting tillage practices. Soil and Tillage Research, 94, 425-440. 
Kolchakov, I., Rousseva, S., Georgiev, B., Stoychev, D., 2005. Soil survey and soil mapping in Bulgaria. In: Jones, R.J.A., Houšková, B., Bullock, P., Montanarella, L. (Eds.): Soil Resources of Europe, second edition. European Soil Bureau research Report No 9. EUR 20559 EN. Office for Official Publications of the European Communities, Luxembourg. 83-87.

Li, Y., Zhu, X., Tian, J., 1991. Effectiveness of plant roots to increase the anti-scourability of soil on the Loess Plateau. Chinese Science Bulletin, 36, 2077-2082.

Lichner, L., Holko, L., Zhukova, N., Schacht, K., Rajkai, K., Fodor, N., Sandor, R., 2012. Plants and biological soil crust influence the hydrophysical parameters and water flow in an Aeolian sandy soil. J. Hydrol. Hydromech., 60, 4, 309-318.

Martínez-Murillo, J.F., Nadal-Romero, E., Regüés, D., Cerdà, A., Poesen, J. 2012. Soil erosion and hydrology of the western Mediterranean badlands throughout rainfall simulation experiments: A review. Catena. doi: 10.1016/j.catena. 2012.06.001

Perriet, A., Doussan, C., Capowiez, Y., Bastardie, F., Pages, L., 2007. Root Functional Architecture: A Framework for Modeling the Interplay between Roots and Soil. Vadose Zone Journal, 6, 2, 269-281.

Reubens, B., Poesen, J., Danjon, F., Geudens, G., Muys, B., 2007. The role of fine and coarse roots in shallow slope stability and soil erosion control with a focus on root system architecture: a review. Trees, 21, 385-402.

Rousseva, S., 1994. Modifications in physical properties of Chromic Luvisols due to erosion. Proc. V Nat. Symposium with International Participation "Physics - Agriculture", Sofia (23-24 Nov. 1994), 149-153.

Rousseva, S., Lazarov, A., Tsvetkova, E., Marinov, I., Malinov, I., Krumov, V., Stefanova, V., 2006. Soil erosion in Bulgaria. In: Boardman, J., Poesen J. (Eds.): Soil Erosion in Europe, John Wiley \& Sons Ltd., London. 167-181.

Rousseva, S., 2012. Factors and rates of soil erosion in the Balkan Peninsula. In: Christov, I. (Ed.): Proceedings of In- ternational Conference "Ecology - Interdisciplinary Science and Practice", Sofia 25-26 Oct. 2012, Part One, 43-47.

Silva, J.S., Rego, F.C., 2003. Root distribution of a Mediterranean shrubland in Portugal. Plant and Soil, 255, 529-540.

Simeonov, P., Bocheva, L., Marinova, T., 2007. A climate study of severe convective storms over Bulgaria: frequency distribution and severity. 4th Europ. Conference on Severe Storms, 10 - 14 Sept. 2007, Trieste, Italy.

Stokes, A., Lucas, A., Jouneau, L., 2007. Plant biomechanical strategies in response to frequent Disturbance: uprooting of phyllostachys nidularia (poaceae) growing on landslideprone slopes in Sichuan, China. American Journal of Botany, 94, 7, 1129-1136.

Varallyay, G., 1992. Central and East European erosion overview. In: Soil erosion prevention and remediation workshop, US-Central and Eastern European Agro- Environmental Program, April 27th - May 1st, 1992, Budapest, Hungary. USDA/SCS, 26-37.

Vateva, V., Lozanova, L., 2006. Influence of mineral fertilization of eroded rangeland on the root system of the range herbaceous vegetation. In: Proceedings of the Ruse University "Angel Kunchev", vol. 45, ser. 1, (subsection Ecology and environmental protection - Soil erosion and erosion control technologies), 152-155.

Vomocil, J.A., 1965. Porosity. In: Black, C.A. (Ed.): Methods of soil analyses. Part 1 Physical and Mineralogical Properties including Statistics of Measurement and Sampling., Agron. Monogr, 9, ASA and SSSA, Madison, WI, USA, 299-314.

Zhou, Z., Shangguan, Z., 2005. Soil anti-scourability enhanced by plant roots. Journal of Integrative Plant Biology, 47, 6, 676-682.

Zhou, Z.C., Shangguan, Z.P., 2007. The effects of ryegrass roots and shoots on loess erosion under simulated rainfall. Catena, 71, 350-355.

Received 25 September 2012 Accepted 3 January 2013 